\title{
ABCD1 Gene
}

National Cancer Institute

\section{Source}

National Cancer Institute. ABCD1 Gene. NCI Thesaurus. Code C142193.

This gene plays a role in the import of fatty acids and acyl-coenzyme A (acylCoA)-

conjug ated fatty acids into the peroxisome. 